\title{
EDITORIAL
}

\section{Tecnologías de producción en CSS y sostenibilidad de estos sistemas}

\author{
Technologies of soilless culture and their sustainability
}

Julio Muro Erreguerena

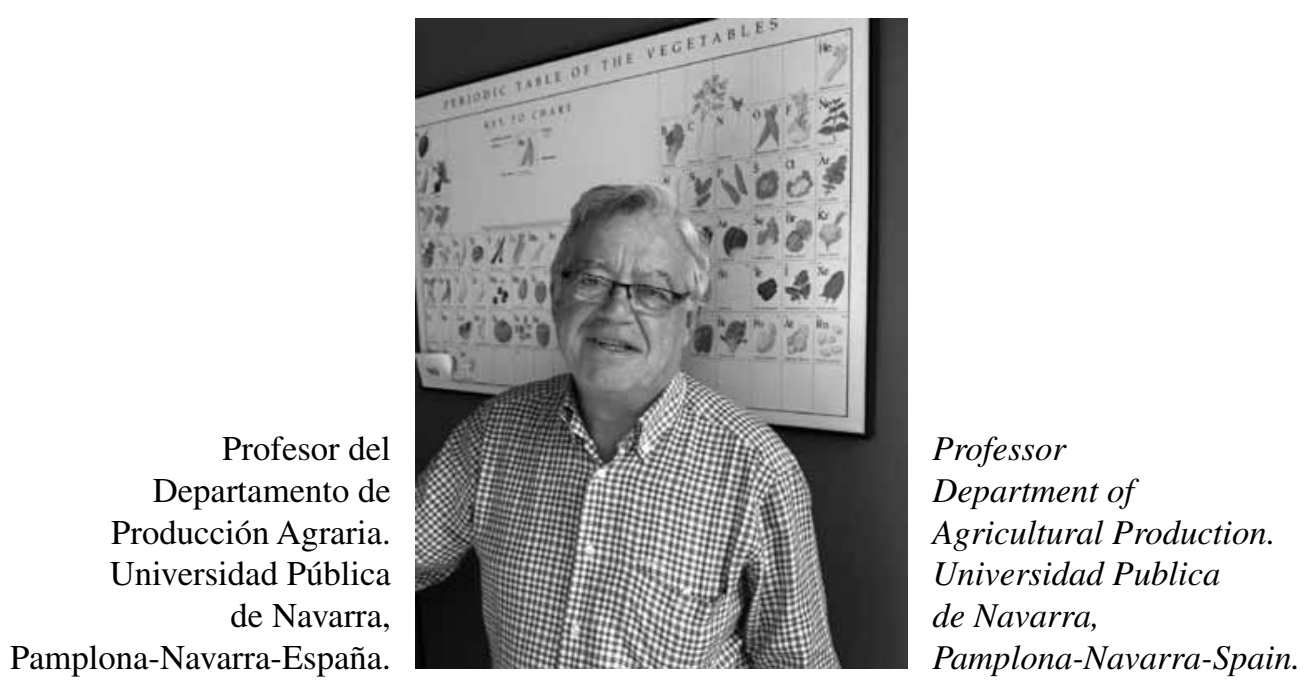

Los cultivos sin suelo (CSS), cultivos fuera de suelo (CFS) o soilless culture son términos sinónimos para denominar todo un conjunto de técnicas y equipamientos que poseen en común la independencia de la utilización del suelo natural para la obtención de producciones vegetales.

El desarrollo de los cultivos CSS está ligado, por un lado, al desarrollo agrotécnico y económico de los países, Holanda es el mejor ejemplo de ello, $\mathrm{y}$, por otro, a la oportunidad de obtener de ellos las ventajas que se derivan de su utilización (mayores rendimientos respecto al cultivo en suelo y mayor calidad de las producciones), como es el caso del cultivo de ornamentales en Latinoamérica.

Existen múltiples sistemas, desde la hidroponía pura (cultivo con sus raíces abastecidas exclusivamente con solución nutritiva, sin intervención de ningún sustrato) hasta los sistemas más utilizados actualmente, que son los sistemas que utilizan sustratos con alta capacidad de aireación y que reciben la solución nutritiva.

Los CFS de hidroponía pura, en balsas con agua, fueron los primeros en desarrollarse en su versión
Soilless culture is the term used to denominate a group of techniques and equipment which have in common their independence from the use of natural soil to obtain vegetable products.

The development of soilless culture is linked to the agro-technical and economic development of countries, Holland being the best example, and also to the opportunity to obtain the advantages of its use (better yields compared to cultures in soil and better quality of products), as in the case of ornamental plants in Latin America.

There are a number of systems, from pure hydroponic culture (roots given only nutritive solution, with no solid substrate) to systems with high aeration capacity substrates which receive the nutrient solution, which are currently the most used methods.

Pure hydroponic culture, in rafts or containers, was first developed in modern times by W. F. Gerike, although there are historical precedents such as the Hanging Gardens of Babylon (VI century BC) or the cultivation of the chinampa islands in the lakes of what is currently Mexico City, developed by the 
históricamente moderna, esto ocurrió en 1929 de la mano de W.F. Gerike, aunque como precedentes históricos se citan los Jardines Colgantes de Babilonia (s. VI a.C.) o el cultivo de las chinampas en las lagunas sobre las que se asienta la actual Mexico D.F., y que desarrollaron los primeros aztecas. Tras su evolución tecnológica, hoy existen principalmente dos sistemas de hidroponía pura, el NFT (nutrient film technique) y NGS (new growing system). Ambos son sistemas con solución recirculante, esto es, la solución aplicada a las raíces del cultivo es recogida al final de las canaletas de aplicación (en las que se desarrollan las raíces del cultivo) y vuelta a rebombear y reutilizar en el sistema. Estos son los sistemas denominados de solución recirculante o sistemas cerrados, sistemas que implican un alto grado de tecnificación, de inversión y, sobre todo, de conocimientos químicos tanto sobre soluciones nutritivas como sobre el control de la evolución en su composición en el tiempo (a lo largo de los días) y que obligan a tomar decisiones de corrección química en el momento $(\mathrm{pH}$, conductividad y composición) ya que los cultivos, derivado de la absorción de nutrientes, van variando la composición de la solución. A estas dificultades se añade el control sanitario (hongos especialmente) de la solución recirculante.

Frente a estos sistemas de solución recirculante están los sistemas de solución perdida o sistemas abiertos en los que la solución nutriente es aplicada al cultivo una sola vez, de modo ajustado a las necesidades del mismo. Los drenajes o excedentes de la solución aplicada son recogidos en depósitos y no vuelven a ser utilizados en el sistema.

Este sistema es el más utilizado en España y Europa, por no presentar las complicaciones técnicas, y de inversión, del anterior. Las soluciones nutritivas se preparan de acuerdo con la calidad del agua empleada y las necesidades del cultivo. Normalmente se formulan dos tipos de solución por cultivo: la de fase de crecimiento vegetativo y la de defloración-fructificación. Estas soluciones se calculan una sola vez por un técnico en hidroponía (en función del cultivo y de la composición del agua utilizada) y el productor no tiene más que preparar siempre al misma "receta" para cada uno de sus cultivos. Para facilitar más esta tecnología, para la aplicación de la solución no se requieren sistemas especiales, se utilizan simplemente los sistemas y equipos de riego por goteo (cabezal y goteros), que son sistemas conocidos y relativamente baratos. $\mathrm{La}$ solución nutritiva se aplica sobre sacos alargados (tablas o salchichas) de 20 a 40 litros de capacidad, de algo más de $1 \mathrm{~m}$ de longitud, y que contienen first Aztecs. With technological evolution there are now principally two systems of pure hydroponics, the nutrient film technique and the New Growing System. Both are systems with nutrient recirculation, that is, the solution applied to the roots in culture is collected at the end of the canals (in which the crop roots develop) and re-used in the system. These systems are called recirculation systems or closed systems; they require considerable technology, inversion and especially chemical knowledge about both the nutrient systems and the control of their evolution over time which obliges immediate decisions of chemical correction ( $\mathrm{pH}$, conductivity and composition), since the absorption of nutrients by the crops change composition of the solution. To these difficulties must be added the sanitary control (especially fungi) of the circulating solution.

The second kind of current hydroponics is the systems of lost solution or open systems, in which the nutrient solution is only applied once to the crop, adjusting the amount to its needs. When the solution is removed it is discarded and not used again in the system.

This is the system most used in Spain and Europe, since it is not as technically complicated or costly as the other system. The nutritive solutions are prepared according to the quality of the water used and the needs of the crop. Normally two solutions are used for a crop, one for the vegetative phase and one for flowering-fruiting. These solutions only need to be calculated once by a hydroponics technician, and the producer only has to prepare the same "recipe" for each of his or her crops. What makes this technology even easier is that the application of the solution does not require special systems; drip irrigation systems (drippers and valves), which are well known and relatively cheap, work well. The nutrient solution is applied on elongated (more than $1 \mathrm{~m}$ ) sacks called panels or sausages with a capacity of 20 to $40 \mathrm{l}$ which contain very porous substrates. Possible substrates include coarse sand, ground volcanic rocks (called tezontle in Mexico and picón in the Canary Islands), laterlite, perlite, mine tailings (from carbon mines in Spain), rock wool, cocoanut fiber, wood fiber, etc. The high porosity required of these substrates is indicated by the fact that peat moss does not provide sufficient air and is not used in hydroponics. The substrates most used in Europe are rock wool, perlite and cocoanut fiber, in that order. 
sustratos muy porosos. Como referencia de sustratos posibles de utilizar están: arena gruesa, piedra volcánica machacada (tezontle en México, picón en Canarias-España), arcilla expandida, perlita, restos de extracción mineral (estériles del carbón-España), lana de roca (rockwool), perlita fibra de coco, fibra de madera, etc. Como referencia de la alta porosidad requerida para estos sustratos hay que señalar que la turba (peat moss) no es lo suficientemente aireante y no se utiliza en hidroponía. Los sustratos más utilizados en Europa son, por este orden, lana de roca, perlita y fibra de coco.

La sostenibilidad de los sistemas hidropónicos está especialmente basada en dos aspectos medioambientales: la gestión del agua residual y la gestión del material utilizado como sustrato en los sacos de cultivo.

El agua de drenaje en los sistemas abiertos que ha sido recogida en depósitos, o de los cerrados al final de su vida útil (un mes aproximadamente), debe ser reutilizada posteriormente como solución fertirrigante de otros cultivos de aire libre. Estas soluciones contienen elementos nutrientes que pueden ser utilizados por otros cultivos que se desarrollen al aire libre, mediante su incorporación al agua aplicada mediante sistemas de riego por gravedad, aspersión o goteo. En ningún caso las soluciones drenantes recogidas deben reutilizarse de nuevo como soluciones de cultivo hidropónico (por higiene del cultivo), ni verter a suelos sin cultivo (contaminación de aguas freáticas) o a cauces de agua (riesgo de eutrofización).

Por otro lado, la utilización de diferentes sustratos es un tema muy importante desde el punto de vista de su sostenibilidad. El tipo de sustrato utilizado obedece, en la mayoría de los casos, al sistema de comercialización; normalmente se utilizan los sustratos que se ofrecen en el mercado. Es el caso de la mayoría de los casos en Europa; aquí se utiliza la lana de roca por ser el sustrato mayoritario en oferta, muy fácil de manejar y con un gran soporte técnico de las empresas que lo comercializan, sin embargo este sustrato no es precisamente sostenible ya que al final de su utilización (dos años), cuando está seco, se convierte en un material peligroso en su manipulación debido a las microfibrillas que desprende y que son aspiradas por los manipuladores del sustrato. Aunque se afirma que su uso no es peligroso, los usuarios no piensan lo mismo y, así, en Francia, Holanda o Alemania las empresas fabricantes de este material están obligadas a retirar el producto ya utilizado. Por otro lado, su reciclaje es difícil y costoso. El segundo material más utilizado en España es la perlita, un
The sustainability of hydroponic systems is based especially on two environmental aspects, management of residual water and management of the material used as substrate in the cultivation sacks.

The waste water of open systems which has been collected in deposits at the end of its useful life (about one month) must be later used in fertiirrigation of other crops in soil. These solutions contain nutrient elements which may be used by other open-air crops by incorporating it into the water applied with gravity, spray or drip irrigation systems. The waste solutions should never be re-used as solutions for hydroponic culture (culture hygiene) nor dumped in uncultivated soil (contamination of sub-surface water) or rivers (risk of eutrophication).

The use of different substrates is important in terms of sustainability. The type of substrate used in the majority of cases depends on the commercialization system, since normally the substrates offered on the market are the ones used. This is true in most of Europe, in which rock wool is used because it is the most available, as well as being easy to manage and with great technical support from the companies which sell it; however, its use is not sustainable, since after use (2 years) when it is dry it becomes dangerous to manipulate due to the microfibers which it releases and which are breathed by those people who handle it. Although it has been claimed that its use is not dangerous, its users do not agree, and thus in France, Holland and Germany the companies which make this material are obliged to take it back after it is used. The second most used material in Spain is perlite, which is an inorganic material without as many drawbacks as rock wool (it does not release microfibers), but still produces a residue which must be disposed of, usually by taking it to dumps. It is also used occasionally on crops with clay soil to improve drainage, since it is an inorganic calciferous material which is innocuous for the soil. Cocoanut fiber, the third material most used as substrate in Europe, is the most innocuous of the three; after use it can be and should be applied to soil as an organic additive. The aspect of sustainability is very important, since it provides the opportunity to use aerating organic materials of local or national origin as substrates for hydroponics. In our most recent studies we have developed an easy to obtain substrate based on pine wood fiber (not sawdust), which is produced by the techniques of defibration used in the paper industry. This new substrate works perfectly well in 
material inorgánico que no presenta tantos inconvenientes como el anterior (no emite microfibrillas) pero que no deja de ser un residuo del que hay que deshacerse, normalmente mediante su traslado a vertederos. Ocasionalmente también se puede verter sobre terrenos de cultivo de textura arcillosa para aligerar su drenaje ya que se trata de un material inorgánico cálcico y es inocuo para el suelo. La fibra de coco, el tercer material utilizado como sustrato en Europa, es el material más inocuo de los tres ya que tras su utilización puede, y debería, aplicarse al suelo como enmendante orgánico. Este aspecto de sostenibilidad es muy importante ya que abre la oportunidad de utilización de materiales orgánicos aireantes de obtención local o nacional como sustratos de hidroponía. En nuestros trabajos más recientes hemos desarrollado un sustrato de fácil obtención a partir de fibra de madera de pino (no aserrín), obtenido mediante técnicas de desfibración utilizadas en la industria del papel. El nuevo sustrato funciona perfectamente en ensayos comparativos frente a perlita o lana de roca, presentando resultados de producción en tomate sin diferencias significativas. La utilización de este tipo de materiales orgánicos autóctonos abre una gran oportunidad para su utilización en este tipo de producciones hidropónicas. En México, por ejemplo, se están llevando a cabo trabajos de adaptación del residuo del ágave del tequila tras la extracción de la materia azucarada; lo mismo ocurre en España con la cáscara de almendra machacada. Las posibilidades de obtención de materiales orgánicos a partir de materiales lignocelulósicos son múltiples a partir de recursos locales, teniendo en la madera, a partir de los subproductos de serrerías, el principal material de partida para este objetivo. No hay que olvidar por otro lado la posibilidad de utilizar materiales inorgánicos locales como es el caso del tezontle en México o el picón de Canarias que hemos citado. Estos últimos tienen las posibilidades de expansión muy limitadas por los costas del transporte ya que se trata de materiales pesados pero que son muy útiles para ámbitos de utilización local, en los que el costo de transporte es bajo. En todo caso materiales lignocelulósicos zonales, con posibilidad de ser transportados a largas distancias, o inorgánicos, con posibilidades muy reducidas de trasporte, son dos grupos de materiales de carácter sostenible capaces de hacer frente a los materiales estándar ofertados por las empresas que dominan el sector de los sustratos en hidroponía. tests compared to perlite and rock wool; there were no significant differences in tomato production. The use of this kind of native organic material provides a great opportunity for this kind of hydroponic production. In Mexico, for example, studies are adapting the use of the residue of the agave after the sweet material has been extracted for tequila production; there are analogous studies in Spain with crushed almond shells. There are multiple possibilities for obtaining organic materials from lignocellulose material of local resources; wood products based on the byproducts of sawmills are the principal starting point for this objective. There is also the possibility of using local inorganic materials, such as the tezontle in Mexico and picón in the Canary Islands mentioned above. These have very limited possibilities of expansion due to the cost of transport, since they are heavy materials; however, they are very apt for local use in which transport costs are low.

Local lignocellulose materials, which may be transported long distances, and inorganic material with very limited possibilities of transport, are two groups of sustainable materials which can compete with the standard materials offered by the companies which dominate the market of substrates for hydroponics. 